\title{
Global Crisis and its Impact on Indian Economy
}

\author{
Vekariya Sheetal Popatbhai \\ Lecturer, Lt. M. J. Kundaliya Eng. Med. Mahila Commerce \& B.B.A. College, Rajkot, India
}

\begin{abstract}
The Indian economy is a mixed economy. It has acquired this form with the growth of a large public sector since Independence. Nationalization of banks, setting up a number of enterprises in the public sector and such other measures may create an illusion that the economy has advanced towards socialism but in fact socio-economic relations have not undergone any such change as to warrant the conclusion that the Indian economy has drifted away from its capitalist forms.
\end{abstract}

India had a dream run of five years during 2003-08 as the GDP growth averaged nearly $9 \%$ annually for 5 years; the best ever run for five years. The economy began to slow down from the middle of 2007-08. Global recession and credit crisis, which began with sub prime crisis, is affecting almost all economies across the world.

The Bank for International Settlement (BIS) report has succinctly brought out how and why the crisis has occurred. It is a little over a year since the US financial crisis became a global concern. Starting with home loan sector, US banks and lending institutions lent recklessly to borrowers who were not creditworthy and who had no repayment capacity, based on their income levels. Subprime lending spurred acute competition among banks and other lending institutions which resulted in unsafe and indiscriminate lending.

\section{INTRODUCTION - INDIAN ECONOMY}

The Indian economy is a mixed economy. It has acquired this form with the growth of a large public sector since Independence. Nationalization of banks, setting up a number of enterprises in the public sector and such other measures may create an illusion that the economy has advanced towards socialism but in fact socio-economic relations have not undergone any such change as to warrant the conclusion that the Indian economy has drifted away from its capitalist forms.

Due to private ownership of the means of production and profitinduced commodity production makes India as mixed economy. Presence of a large public sector in India along with free enterprise makes the character of the economy as mixed. The public sector in India has not been developed for any ideological reasons. Its creation was a historically necessity. At the time of Independence the private enterprise had neither the resources nor the will to undertake the task of industrial development on a massive scale. Furthermore, country's transport system, energy sources and certain other components of the infrastructure were undeveloped. To be brief, though the economy emerging from its colonial past needed a 'big push', the conditions prevailing in the country were hardly conducive to development in general and industrialization in particular.
In India, the assumption that " the state in general and the government in particular can act as an agent of desirable socioeconomic change independently of the various interest groups" does not hold good and thus accentuation of income inequalities and a rise in the absolute number of poor is inevitable.

\section{ECONOMY CRISIS}

The problems of the economy in the country which assumed crisis proportion in 1991 did not develop suddenly. The origin of crisis is directly attributable to the cavalier macro management of the economy during the 1980s which led to large and persistent macroeconomic imbalances. The strategy of development, not withstanding its limitation, cannot be blamed for this crisis. The widening gap between the revenue and expenditure of the government resulted in growing fiscal deficits which had to be met by borrowing at home. The internal imbalance in the fiscal situation and the external imbalance in the payments situation were closely related, through the absence of prudence in the macro management of the economy.

The Gulf crisis in the late 1990 sharply accentuated macroeconomic problems. There was also political instability in the country at this juncture. All these developments together eroded international confidence in the Indian economy and, as a result, this country's credit rating in the international capital market declined steeply. However, it has to be recognized that the problems of the economy did not assume crisis proportions abruptly. But by 1990 the situation had changed so much that the minor oil shock made disproportionately large impact on the economy and a macroeconomic crisis erupted in the form of:

\section{Unsustainable fiscal deficit}

\section{Unsustainable current account deficit and}

3. Accelerating inflation.

\section{GLOBAL CRISIS}

India had a dream run of five years during 2003-08 as the GDP growth averaged nearly $9 \%$ annually for 5 years; the best ever run for five years. The economy began to slow down from the middle of 2007-08. A 9 per cent growth apparently could not be sustained, being clearly beyond India's potential rate of growth which has been estimated by more than one agency to be around 8.5 per cent. And as the economy overheated, the central bank tightened credit slowly initially but harder since 2006-07.

As an expected outcome, the economy began to slow down. Some of us had argued that the tightening was going too far and over reacting to inflationary fears, which largely arose from global factors. The policy makers and none of us had foreseen the external shock arising from the global crisis, which began with the financial meltdown in the US. The interesting question therefore is: what would India's growth rate have been in 


\section{www.ijtsrd.com}

response to the policy measures without the global crisis, compared to what it is likely to be in the context of the ongoing global crisis.

\section{INDICATORS OF GLOBAL CRISIS:}

Leading economic indicators are variables that are considered to have significant influence on the future level of economic activity in the country. These indicators give advance signals about the likely growth rate and in this case we are able to use this to forecast GDP growth five quarters ahead of the value of leading indicators. The predictive quality of Leading Economic Indicators has earned them their name of being 'leading' indicators. It had predicted a growth of GDP at 9.2 per cent for 2007-08 in November 2007, while most agencies had predicted a lower growth rate of 8.5 per cent or below that year, as against the actual growth rate of 9 per cent. Then again, ICRIER was first in predicting a growth rate (before the crisis erupted) of 7.8 per cent for 2008-09 in July this year, an estimate that thereafter was adopted by others, including both the RBI and the finance minister.

For constructing the leading indicators index, the following ten indicators have been used

$>$ Production of machinery and equipment
$>$ Sales of heavy commercial vehicles
$>$ Non-food credit
$>$ Railway freight traffic
$>$ Salen of the corporate sector
$>$ Fuel and metal prices
$>$ Real rate of interest
$>$ BSE Sensex
$>$ GDP growth rates of the country

The global crisis is likely to bring India's growth rate to below 6 per cent in 2008-09. With the first half GDP growth rate already known, this implies a sharp slowdown in the next two quarters.

In the first half of next year, the economy would have grown below 7 per cent in the absence of the external crisis. The global crisis may reduce Indian growth rate to as low as less than 4 per cent in 2009-10.

We should prepare the people for slowdown in employment generation and plan for counter cyclical measures urgently.

This should imply an immediate reduction in interest rates to bring down the cost of capital and a quick and thorough review of government procedures that vitiate the investment environment and hike up transactions costs.

The new millennium has seen the Indian economy surge ahead breaking all previous barriers. The Indian economy grew at 9.6 per cent in 2006-07 and 9 per cent in 2007-08, emerging as the second fastest growing major economy in the world. Growth has been supported by market reforms, rising foreign exchange reserves, huge foreign direct investment (FDI) inflows and a flourishing capital market.
The economy has been growing at an average growth rate of 8.8 per cent in the last four fiscal years (2003-04 to 2006-07), with the 2006-07 growth rate of 9.6 per cent being the highest in the last 18 years. The industrial and service sectors have contributed a major part of this growth, suggesting the structural transformation underway in the Indian economy.

India's central banking authorities Reserve Bank of India maintains that zooming inflation that the country witnessed in the first quarter of the current fiscal 2008-09 and beyond - from 7.7 per cent at end-March 2008 to 11.9 per cent by July 12, 2008- cane be attributed to the impact of some pass-through of higher international crude oil prices to domestic prices as well as continued increase in the prices of iron and steel, basic heavy inorganic chemicals, machinery and machinery tools, oilseeds/edible oils/oil cakes and raw cotton on account of strong demand, international commodity price pressures and lower domestic 2007-08 rabi production of oilseeds. The seasonal hardening of vegetables prices as well as increase in the prices of textiles has also contributed to the rising inflation during 200809 so far. Inflation in India is estimated on the basis of fluctuations in the wholesale price index (WPI).

\section{REASONS}

\section{Genesis Of The Crisis}

The Bank for International Settlement (BIS) report has succinctly brought out how and why the crisis has occurred. It is a little over a year since the US financial crisis became a global concern. Starting with home loan sector, US banks and lending institutions lent recklessly to borrowers who were not creditworthy and who had no repayment capacity, based on their income levels. Subprime lending spurred acute competition among banks and other lending institutions which resulted in unsafe and indiscriminate lending. This type of lending resulted in dilution of lending standards and brought about total degeneration of banking.

\section{Prudent policy base}

According to the Indian Prime Minister India is not insulated from the global financial crisis, but Indian economy is nor that vulnerable. Indian banks are relatively free from the crisis because of the prudent and judicious policies adopted and implemented by the Indian government and the Reserve Bank of India (RBI). Prudent policy base provided relative immunity to Indian banks from the major adverse effects of global financial crisis. Another important factor was that India is not allowing full capital account convertibility of the rupee. If that was done, India would have been exposed too much greater adverse impacts and contagion from the crisis prevailing. The risks emanating from the global crisis will continue for the sometime. Although India is relatively free from the major adverse effects of the crisis, it is likely to face some jitters.

\section{Drawing lessons}

Banks in India have to draw suitable lessons from the US financial crisis and build strategies avoiding the pitfalls. The BIS report has some useful messages for Indian banks. 


\section{www.ijtsrd.com}

\section{Comprehensive failure}

The financial crisis in US is the cumulative result of many debatable practices adopted by banks over the years like aggressive lending to those who were ineligible for credit based on income norms and repayment capacity, securitization of such loans by way of new products and derivatives.

\section{Emphasis on recoveries}

In US even smaller banks and regional lenders which have been suffering from the housing slump are now getting hit by rising loan delinquencies as the economic downturn deepens.

\section{Audit and inspection}

Banks today find it difficult to maintain the minimum required controls expected of them in a new complex and increasingly regulated business environment. The traditional audit and inspection provide assurance that control systems are adequate and function satisfactorily.

\section{Corporate governance}

A vital requirement during periods of financial crisis is to focus on good corporate governance. The corporate governance philosophy of banks has to be based on pursuits of sound business ethics and strong professionalism that aligns the interests of all stakeholders and the society at large.

\section{IMPORTANT ISSUES}

- The incentives effects of government sponsored safety nets on senior bank managers.

- The efficacy of capital adequacy norms, particularly the revised norms mandated by the Banks for International Settlements (BIS) - also known as the Basel II norms.

- The adequacy of current norms for accounting disclosure.

- The role of the central banks as the lender of last resort in crisis situation.

- Compensation structures in financial companies and their impact on risk management.

- The need for coordinated regulation for different entities in the financial sector.

\section{SUGGESTIONS}

There are some suggestions about appropriate policy and managerial responses with focus on three areas:

1. Regulatory responses

2. Accounting policies

3. Role of incentives
The combination of cheap money and low interest rates led to

- Asset price inflation, particularly, evident in real-estate. Higher real-estate prices contributed to the wealth effect which kept consumer spending buyout through the decade.

- A sharp increase in leveraged buyouts.

- A scramble by fund managers and bankers for assets with higher expected returns.

- Greatly increased use of leveraged investment strategies by hedge funds and others.

- The development of increasingly complex risk management tools. In particular, the use of credit derivatives has led to questions about the concentration of risks in the financial sector and the ability of the financial sector to absorb shocks.

- Opening up the discount window to investment banks.

- Allowing a much larger variety of securities as collateral for the discount window.

- Providing backup liquidity to money market mutual funds and commercial paper markets.

\section{REGULATORY RESPONSES:}

Several developments complicated the regulatory response to the crisis. While banks had traditionally depended on retail deposits for their funding, wholesale funds became an increasingly important component of their funding. In particular the commercial paper market became an important component of bank funding. Any disruption in bank's access to wholesale funding would impact their ability to lend.

While liquidity has always been a concern for banks and bank regulators, the recent crisis has demonstrated how liquidity can quickly disappear and how this can lead to cascading effects through different segments of the financial sector.

The key is to reduce or eliminate misuses and fraud and the instances of using complex techniques and instruments without fully understanding them. Part of the answer lies in changing the approach to bank regulation. A second broad lesson is the need for consistent regulation across the financial sector, particularly given the convergence in the activities of different financial institutions. In India, for example, insurance companies and mutual funds have overlapping business interests.

\section{ACCOUNTING POLICIES}

A significant lesson from the crisis is the need for transparent accounting practices. Hiding significant portions of the balance sheet and using internally generated models to price securities lead to opaque and misleading statement about an entity's true financial status. In addition, many of these transactions are short term in nature and including them would mean difficulties in comparing results year on year. 


\section{INCENTIVES AND THE CRISIS}

Incentives have played a very important role in exacerbating the crisis in two distinct ways. First is the role of corporate compensation structures in institutional risk taking? The second broad area is the impact of the regulatory backup on risk taking in the financial sector.

\section{MEASURES \& CONCLUSION}

Global recession and credit crisis, which began with subprime crisis, is affecting almost all economies across the world. The RBI has taken following measures to infuse additional liquidity in the system:

\section{$>$ MONETARY MEASURES}

The repo rate under the liquidity adjustment facility has been reduced by a cumulative 150 basis points since October 20, 2008.

\section{$>$ RUPEE LIQUIDITY}

In order to enhance rupee liquidity, the cash reserve ratio (CRR) has been reduced by a cumulative 3.5\% points of Net Demand and Time Liabilities (NDTL) since October 11, 2008.

The statutory liquidity ratio (SLR) has been reduced by $1 \%$ point, that is, from $25 \%$ of NDTL to $24 \%$.

\section{FOREX LIQUIDITY}

The RBI announced that it would continue to sell foreign exchange through agent banks to augment supply in the domestic foreign exchange market or intervene directly to meet any demand supply gaps.
The RBI announced that it would institute special market operations to meet the foreign exchange requirements of public sector.

\section{$>$ CREDIT DELIVERY}

In view of the difficulties being faced by exporters on the account of the weakening of external demand, it has been decided to extend the period of entitlement of the first slab of pre-shipment rupee export credit, currently available at a concessional interest rate ceiling of the benchmark prime lending rate minus $2.5 \%$ points from 180 days to 270 days with immediate effect.

\section{CONCLUSION}

The overall analysis of the intervention to the Indian economy by the global financial crisis depicts that this crisis is the end of the beginning still it has long way to go but one good news for the Indian economy is the Indians banks are stable to capitalize the market but together contribution of the factors to the GDP requires some stringent actions from the concerned authorities

\section{REFERENCES}

$>$ Economic Times, News Paper

$>$ www.google.com

$>$ http://economictimes.indiatimes.com

$>$ UHERO Global Economic Forecast, University of Hawai'i Economic Research Organization, November2008

$>$ Report from Gurgaon Workers News

$>$ Statement of Governor, Reserve Bank of India, and Leader of the Indian delegation at the International Monetary and Financial Committee Meeting, at the International Monetary Fund, Washington DC, on October 11, 2008) 